\title{
Electrochemical Performance Improvement of the Catalyst of the Methanol Microfuel Cell Using Carbon Nanotubes
}

\author{
Mohammad Kazemi Nasrabadi $\mathbb{D}^{1},{ }^{1}$ Amir Ebrahimi-Moghadam, ${ }^{2}$ Ravinder Kumar ${ }^{D},{ }^{3}$ \\ and Narjes Nabipour ${ }^{4}$ \\ ${ }^{1}$ Aerospace Engineering Department, Shahid Sattari Aeronautical University of Science and Technology, Tehran, Iran \\ ${ }^{2}$ Faculty of Mechanical Engineering, Shahrood University of Technology, Shahrood, Iran \\ ${ }^{3}$ Department of Mechanical Engineering, Lovely Professional University, Phagwara, Punjab 14411, India \\ ${ }^{4}$ Institute of Research and Development, Duy Tan University, Da Nang 550000, Vietnam
}

Correspondence should be addressed to Mohammad Kazemi Nasrabadi; kazemi@ssau.ac.ir

Received 17 August 2020; Accepted 20 May 2021; Published 28 May 2021

Academic Editor: Nicole Vorhauer-Huget

Copyright ( $\odot 2021$ Mohammad Kazemi Nasrabadi et al. This is an open access article distributed under the Creative Commons Attribution License, which permits unrestricted use, distribution, and reproduction in any medium, provided the original work is properly cited.

\begin{abstract}
In this research, the electrocatalytic activity of platinum-ruthenium nanoparticles on carbon nanotubes and carbon black in methanol oxidation reaction has been investigated. Moreover, the electrochemical performance of a single passive direct methanol fuel cell run by these two different electrocatalysts has been reported. Physical characterization and electrochemical tests reveal the superiority of PtRu on carbon nanotubes. Based on the voltammetry outcomes, it was found that methanol oxidation reaction kinetics has been improved on the nanotube-supported catalyst. The current density of oxidation reaction has increased up to $62 \%$ in nanotube sample compared to carbon black-supported one. The electrochemical test results have shown that the carbon nanotubes increase the performance of the microfuel cell by $37 \%$ at maximum power density, compared to the carbon black. Moreover, the resistance of the samples supported by carbon nanotubes to poisonous intermediate species has been found $3 \%$ more than carbon black-supported one. According to the chronoamperometry test results, it was concluded that the performance and sustainability of the carbon nanotube electrocatalyst show a remarkable improvement compared to carbon black electrocatalyst in the long term.
\end{abstract}

\section{Introduction}

Different clean energy technologies have been evaluated in recent years to replace the current energy systems, which use fossil fuels [1]. Among different power generation technologies with lower greenhouse gas emissions in comparison with the conventional fossil fuel-based systems, fuel cells have some advantages [2]. The fuel cells convert the chemical energy of the fuel directly into heat and power through a set of electrochemical reactions. The main part of the fuel cell structure is the membrane electrode assembly (MEA), which specifies the type and the function of the cell [3]. High efficiency, environmental compatibility, simple maintenance, zero noise pollution, and ability to employ different fuels such as hydrogen, methanol, and ethanol, are some of the benefits of the fuel cells [4]. Direct methanol fuel cells (DMFCs) are a subcategory of polymer-exchange membrane fuel cells in which methanol is consumed as fuel. The utilization of liquid fuel facilitates the safer use of this technology for a wider range of applications, from portable electronic devices to electric vehicles [5].

Even though much research has been conducted on methanol fuel cells during the recent two decades, there are still challenges that should be addressed. One of these challenges is the high ratio of Pt in the catalyst layer [5]. Improving the properties of the catalyst substrate can lead to higher efficiency and reduce the consumption of the expensive Pt. Due to high specific surface area, high electrical conductivity, and low price, carbon black (CB) is commonly used as the electrocatalyst support in DMFCs. On the other 
hand, $\mathrm{CB}$ tends to corrode rapidly and suffers from low efficiency in metal catalyst utilization [6]. Efforts are focused on superseding new materials with extraordinary physical and electrical properties such as carbon nanotube (CNT) [7].

Graphite nanofiber has been investigated as the $\mathrm{Pt}$ support in proton exchange membrane fuel cell. The outcomes showed that the support corrosion was reduced by one-half, and catalyst stability was improved compared to Pt/CB [8]. Three-dimensional graphene-supported PtAu composite has been characterized for the methanol oxidation reaction. The outcomes indicated high specific surface area and higher electrocatalytic activity compared with commercially used Pt/CB [9]. The electrochemical characterization of ultrasonically treated multiwalled carbon nanotubes as the PtRu support illustrated the superiority of catalyst in electrochemically active surface area and activity in the methanol oxidation reaction [10]. By comparing MWCNT/Pt, DWCNT/Pt, and SWCNT/Pt, Dongmulati and Baikeri [11] concluded that using $\mathrm{MWCNT/Pt}$ as a catalyst in fuel cells is better than two other ones due to its high specific surface area.

Noncarbon catalyst supports such as mesoporous silicas and metal oxide-based materials have attracted attention in recent years. Yu et al. [12] used $\mathrm{Pt}-\mathrm{Ru}-\mathrm{NiTiO}_{3}$ nanoparticles and found that it has higher catalytic activity than PtRu/C, and the onset potential became $60 \mathrm{mV}$ more negative. Bilondi et al. [13] coated PtRu nanoparticles with cerium oxide $\left(\mathrm{CeO}_{2}\right)$ which increased the oxidation reaction activity of methanol compared to bare PtRu electrocatalyst, and the power density increased $1 \%$ per each $\mathrm{cm}^{2}$.

Since there are few studies focused on the passive DMFCs, the current research has concentrated on the comparison of the electrochemical performance of PtRu/ CNT and PtRu/CB. In the next step, the authors have fabricated MEAs comprised of PtRu/CNT and PtRu/CB on the anode side and Pt/CNT and Pt/CB on the cathode side to investigate the electrocatalytic performance under the operating condition of a single passive DMFC.

\section{Materials and Methods}

2.1. Electrocatalyst Synthesis. Carbon black, multiwalled carbon nanotubes, hexachloroplatinic acid $\left(\mathrm{H}_{2} \mathrm{PtCl}_{6} \cdot 6 \mathrm{H}_{2} \mathrm{O}\right)$, ruthenium chloride $\left(\mathrm{RuCl} .3 \mathrm{H}_{2} \mathrm{O}\right)$, 2-propanol, sodium borohydride $\left(\mathrm{NaBH}_{4}\right)$, sodium hydroxide $(\mathrm{NaOH})$, acetone, and deionized water have been used to synthesize and prepare the catalyst samples. In this study, the impregnation reduction method has been employed for the synthesis of electrocatalyst PtRu with a 1:1 atomic ratio, using sodium borohydride as a reducing agent and isopropanol as the solvent. $100 \mathrm{mg}$ of $\mathrm{CB}$ or MWCNT has been dispersed homogeneously in $100 \mathrm{~mL}$ of a solvent consisting of isopropyl alcohol (IPA) and deionized water in the ratio of $2: 1$ in the ultrasonic probe device for 1 hour. After that, the required amount of platinum and ruthenium solution $(20 \%$ of PtRu catalyst by weight) is added to the suspension and is put on the stirrer at the ambient temperature for one more hour. In the next step, the $\mathrm{pH}$ of the solution has been set to 10 using $0.5 \mathrm{M}$ of $\mathrm{NaOH}$ solution. Then, the required amount of $0.1 \mathrm{M} \mathrm{NaBH}_{4}$ solution in deionized water as the reducing agent was added drop by drop to the suspension on the magnetic mixer at $60^{\circ} \mathrm{C}$ for 2 to 3 hours. The synthesis process is continued for 12 hours at ambient temperature to complete the reduction reaction. Finally, the electrocatalyst has been washed and centrifuged several times and dried at $60^{\circ} \mathrm{C}$ in a vacuumed oven for 12 hours [2].

2.2. Physical Measurements. The crystallite structure has been studied by X-ray diffraction (XRD) technique using X'Pert Philips (PW3040) diffractometer with $\mathrm{Cu}-\mathrm{K} \alpha$ $(\lambda=1.5406 \AA)$ source at $40 \mathrm{kV}$ and $40 \mathrm{~mA}$. The surface morphology of the electrocatalysts was determined by scanning electron microscopy (SEM, Nova NanoSEM 450) and transmission electron microscopy (TEM, Philips EM208S) at $100 \mathrm{kV}$. To investigate the presence and percentage of key elements, energy-dispersive X-ray spectroscopy (EDX) was employed by the Bruker XFlash module.

2.3. Electrochemical Measurements. Voltammetry is the main tool to gain important information about the performance of the catalyst and some of its crucial properties including active surface area, activity, and durability in MOR. In this research, a three-electrode cell connected to a potentiostat (NANO RNF) has been utilized to determine the electrochemical performance of electrocatalysts. It is comprised of a glassy carbon electrode (GCE) with a diameter of $2 \mathrm{~mm}$ as the working electrode, the platinum plate electrode as the counterelectrode, and a half-cell of $\mathrm{Ag} / \mathrm{AgCl}$ as the reference electrode.

To prepare catalyst ink, $1 \mathrm{mg}$ of $\mathrm{PtRu} / \mathrm{C}$ electrocatalyst has been dispersed in $300 \mu \mathrm{L}$ of deionized water and isopropanol in a ratio of $1: 5$. Then, $20 \mu \mathrm{L}$ of $5 \%$ Nafion solution was added as an ionomer to facilitate the exchange of the ions produced in the oxidation reaction. An ultrasonic bath for $30 \mathrm{~min}$ has been employed to disperse catalyst ink uniformly. After this step, $10 \mu \mathrm{L}$ of catalyst ink has been coated on the GCE surface under infrared light. The amount of loaded PtRu on electrode surface area is calculated as $0.2 \mathrm{mg} / \mathrm{cm}^{2}$.

Voltammetry measurements including cyclic voltammetry $(\mathrm{CV})$ and chronoamperometry have been performed at room temperature in $0.5 \mathrm{M} \mathrm{H}_{2} \mathrm{SO}_{4}$ containing $1 \mathrm{M}$ methanol solution as an electrolyte in an oxygen-free condition [7].

The schematic diagram of the methodology process has been illustrated in Figure 1.

\section{Results and Discussion}

3.1. Microscopic Analysis. The surface morphology and nanostructure of the electrocatalysts have been investigated by SEM and TEM analyses. Figures 2(a) and 2(b) present the SEM images of CB and CNT, respectively. As can be observed, there is a distinct structural difference between $\mathrm{CB}$ and CNT. CB primary particles are spherical with a diameter of $50 \mathrm{~nm}$ and form aggregated clusters, while the twisted seaweed structure of CNT has formed a porous network. 


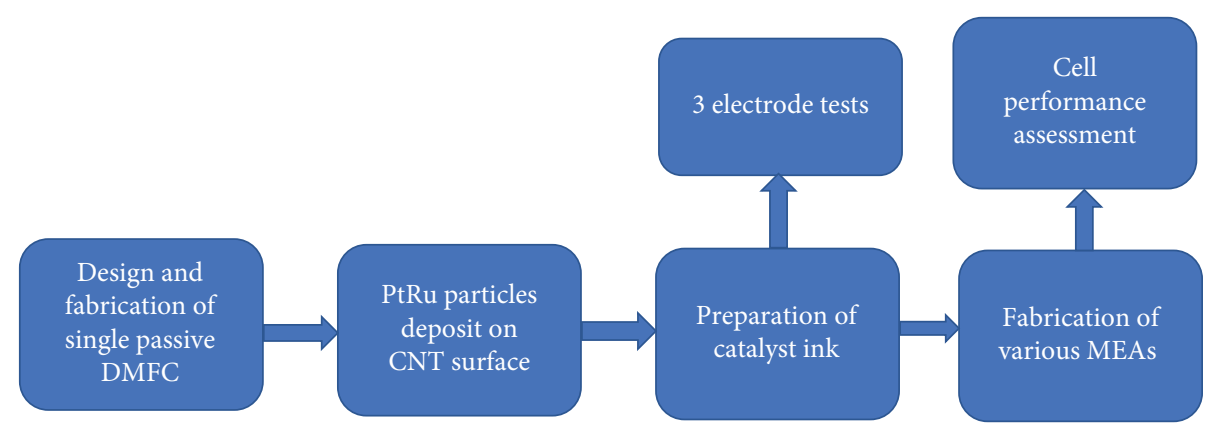

Figure 1: Schematic view of the methodology.
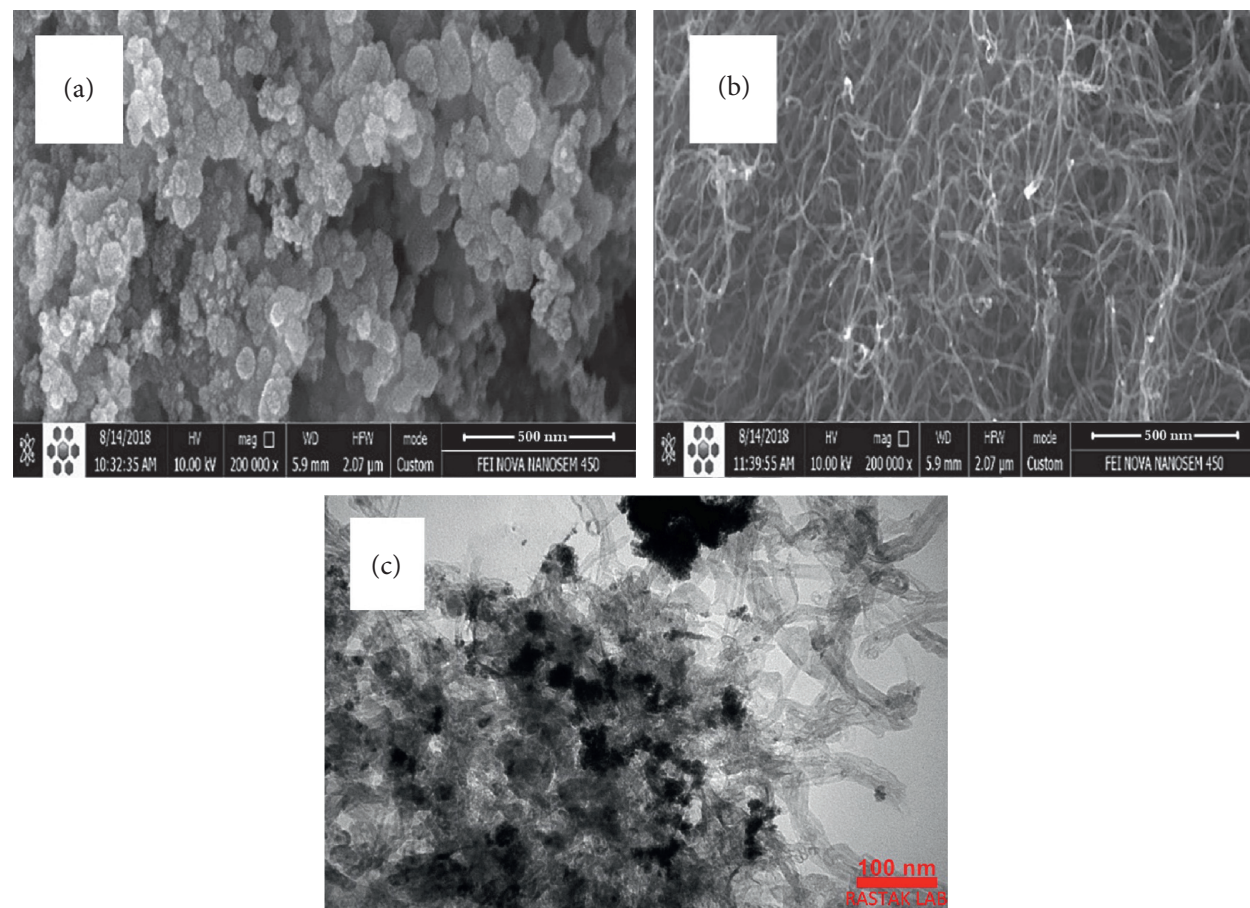

Figure 2: SEM images of CB (a) and CNT (b). TEM image of PtRu/CNT (c).

Moreover, the TEM image of the synthesized PtRu bimetallic electrocatalyst on CNTs at the scale of $100 \mathrm{~nm}$ is presented in Figure 2(c). It is obvious that the agglomerated metal nanoparticles are very well distributed on the CNT surface. The large surface area of CNTs has the potential to absorb metal nanoclusters more efficiently than that of $\mathrm{CB}$ [14].

The composition of chemical elements in synthesized samples is determined using the EDX test (Figure 3). According to the EDX analysis results, the real weight percentage of $\mathrm{PtRu}$ is $22 \%$ (atomic percentage of $\mathrm{Pt}, \mathrm{Ru}$, and $\mathrm{CB}$ is $1.2 \%, 1 \%$, and $97.8 \%$, respectively) and the real weight percentage of $\mathrm{Pt}$ is $21 \%$ (atomic percentage of $\mathrm{Pt}$ is $1.6 \%$ ) which indicates that the synthesis of metal catalyst on the carbon support is well done [15]. The real amount of Pt and $\mathrm{PtRu}$ in all of the samples is about the same as the theoretical value of $20 \%$.
3.2. Spectroscopic Analysis. Figure 4 shows the XRD results of $\mathrm{PtRu} / \mathrm{CB}$ and $\mathrm{PtRu} / \mathrm{CNT}$ samples. The first diffraction peak appeared at the angle of $26^{\circ}$ and $27^{\circ}$ corresponds to the graphite C (002) base plane. The XRD patterns of both electrocatalysts display four diffraction peaks related to the face-centered cubic crystal structure of $\mathrm{Pt}$, corresponding to the (111), (200), (220), and (311) planes, while the Ru atoms are replaced in the $\mathrm{Pt}$ crystal structure.

From Figure 4, some crucial data on the PtRu catalysts can be calculated. Table 1 illustrates the calculated parameters. The lower lattice parameter of the electrocatalysts compared with pure $\mathrm{Pt}\left(l_{\mathrm{Pt} / \mathrm{C}}=0.392 \mathrm{~nm}\right)$ indicates that $\mathrm{Ru}$ has entered into the Pt lattice and an alloy of Pt and Ru was formed. The average crystal size and surface area of PtRu/ CNT catalyst are $3.6 \mathrm{~nm}$ and $86 \mathrm{~m}^{2} / \mathrm{g}$, respectively. However, the corresponding data for the PtRu/CB catalyst are $4.56 \mathrm{~nm}$ and $69 \mathrm{~m}^{2} / \mathrm{g}$, respectively. It can be observed from the above 

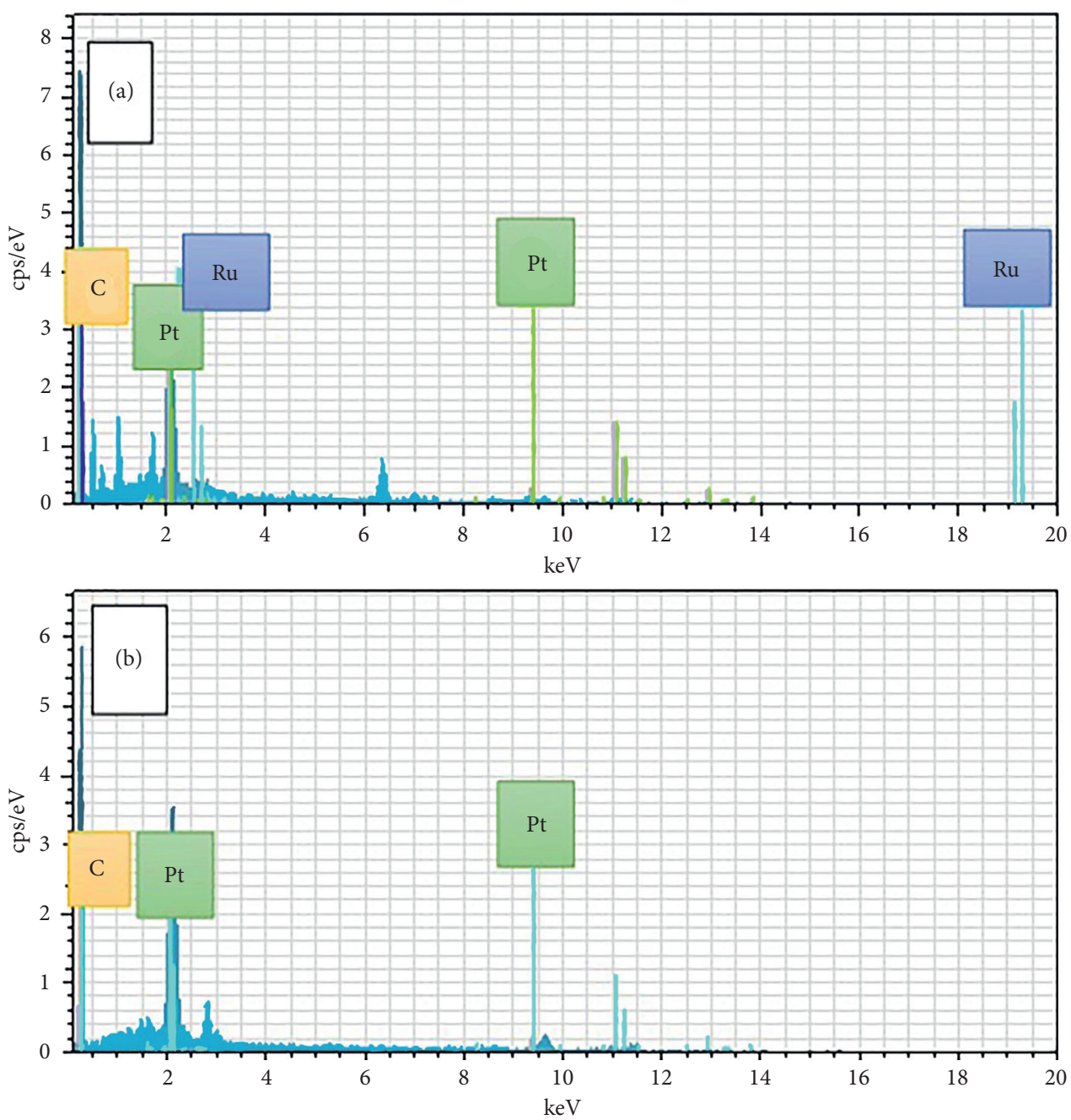

Figure 3: EDX image of (a) PtRu loaded on the anode and (b) Pt loaded on the cathode.

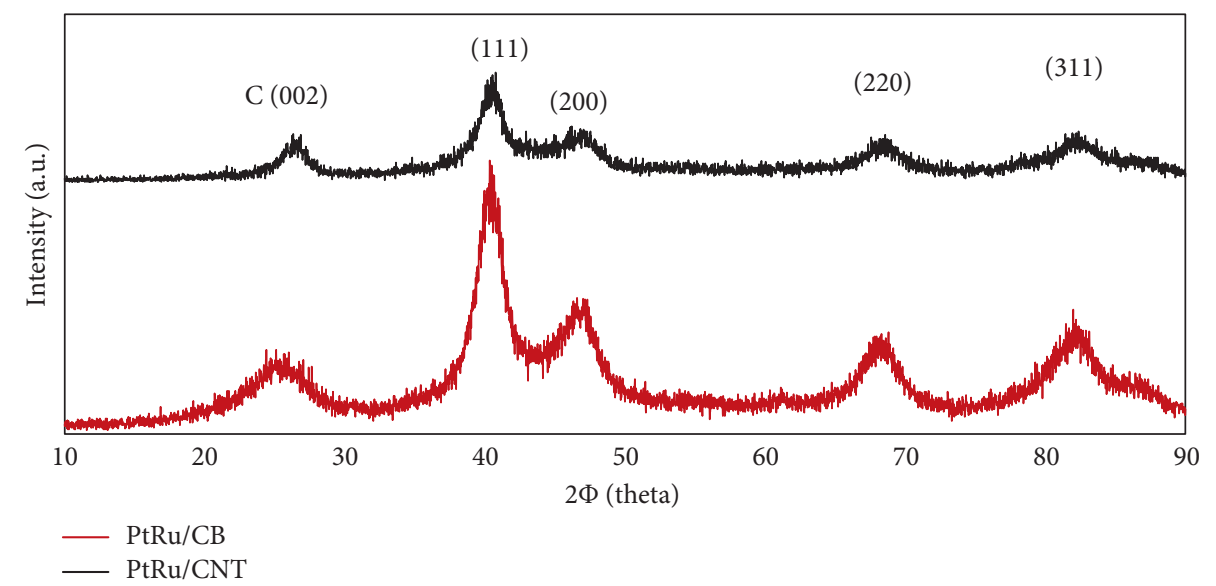

FIgURE 4: The XRD patterns of the synthesized samples for the anodes.

data that although the $\mathrm{Ru}$ atomic fraction is approximately the same, the CNT surface provides stronger active sites for the nucleation and stabilization of metal nanoparticles. The interaction between PtR nanoparticles and CNT surface resulted in a $25 \%$ increase in crystal surface area.
3.3. Electrochemical Analysis. Cyclic voltammetry in a $0.5 \mathrm{M}$ solution of sulfuric acid is an effective method to measure the active electrochemical surface area of different synthesized catalysts. Figure 5 shows the voltammetry graph obtained for PtRu/CB and PtRu/CNT. It is obvious that, by 
TABLE 1: Parameters calculated based on the XRD test.

\begin{tabular}{lcccc}
\hline Catalysts & Crystallite size $(\mathrm{nm})$ & Lattice parameter $(\AA)$ & $\mathrm{Ru}$ atomic fraction & Metal surface area $\left(\mathrm{m}^{2} / \mathrm{g}\right)$ \\
\hline $\mathrm{PtRu} / \mathrm{CB}$ & 4.56 & 3.884 & 0.25 & 69 \\
$\mathrm{PtRu} / \mathrm{CNT}$ & 3.6 & 3.887 & 0.22 & 86 \\
\hline
\end{tabular}

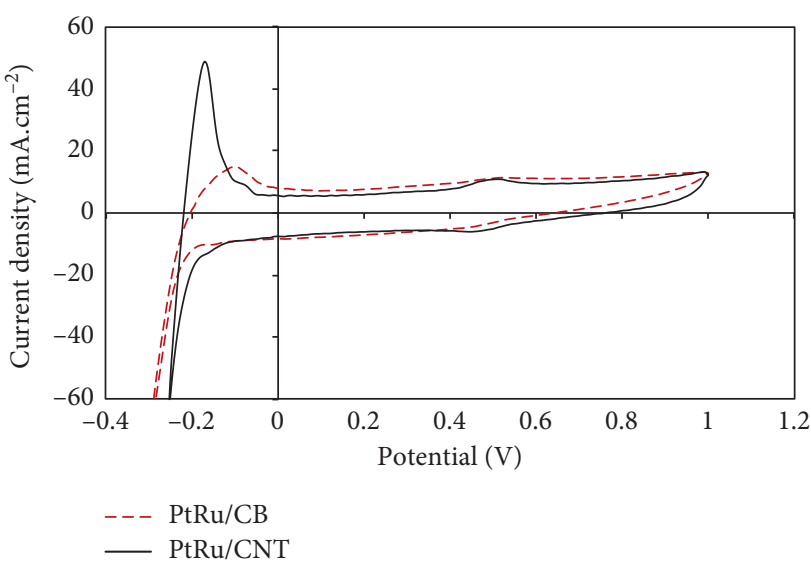

Figure 5: Cyclic voltammetry test of synthesized samples.

increasing the voltage in the forward scan, a current peak has occurred at $-0.19 \mathrm{~V}$ which shows desorption of hydrogen on the electrocatalyst surface. On the other hand, the current drop in the reverse scan is attributed to the adsorption of hydrogen on the electrocatalyst surface. The electrochemically active surface area (ECSA) can be calculated from Figure 5. Using double-layer region correction, the amount of ECSA for PtRu/CNT was calculated at $52.3 \mathrm{~m}^{2} / \mathrm{g}$ which was much higher than that of PtRu/CB catalyst $\left(27.6 \mathrm{~m}^{2} / \mathrm{g}\right)$ [16]. The higher ECSA of the CNT-supported catalyst was attributed to the smaller particle size of the PtRu which provided more accessible active sites in the $\mathrm{PtRu} / \mathrm{CNT}$ catalyst.

The catalyst performance in methanol oxidation reaction (MOR) is investigated by the $\mathrm{CV}$ technique in $0.5 \mathrm{M}$ sulfuric acid and $1 \mathrm{M}$ methanol solution at room temperature. As Figure 6 shows, the first peak at $0.7 \mathrm{~V}$ in the forward scan $\left(I_{f}\right)$ is related to the MOR activity. The second peak at $0.52 \mathrm{~V}$ in the reverse scan $\left(I_{r}\right)$ is related to oxidation of intermediate species created during MOR. $I_{f} / I_{r}$ ratio is used to specify the resistance poisonous intermediate species [17].

$\mathrm{PtRu} / \mathrm{CNT}$ has shown much higher electrochemical activity compared with $\mathrm{PtRu} / \mathrm{CB}$ catalyst. The maximum MOR current density of $47.2 \mathrm{~mA} / \mathrm{cm}^{2}$ is obtained for PtRu/ $\mathrm{CNT}$, which is 1.6 times higher than that for $\mathrm{PtRu} / \mathrm{CB}$ catalyst. Considering the larger ECSA of the PtRu/CNT compared to the $\mathrm{PtRu} / \mathrm{CB}$ catalyst, the MOR results were predictable. Moreover, $I_{f} / I_{r}$ ratio shows that $\mathrm{PtRu} / \mathrm{CNT}$ catalyst is more resistant to $\mathrm{CO}$. To express the results of this analysis more clearly, Table 2 shows the information obtained.

The durability improvement of the electrocatalyst is one of the important research interests in the area of the fuel cell. The long-term electrocatalytic activity and stability of the samples were tested and examined using

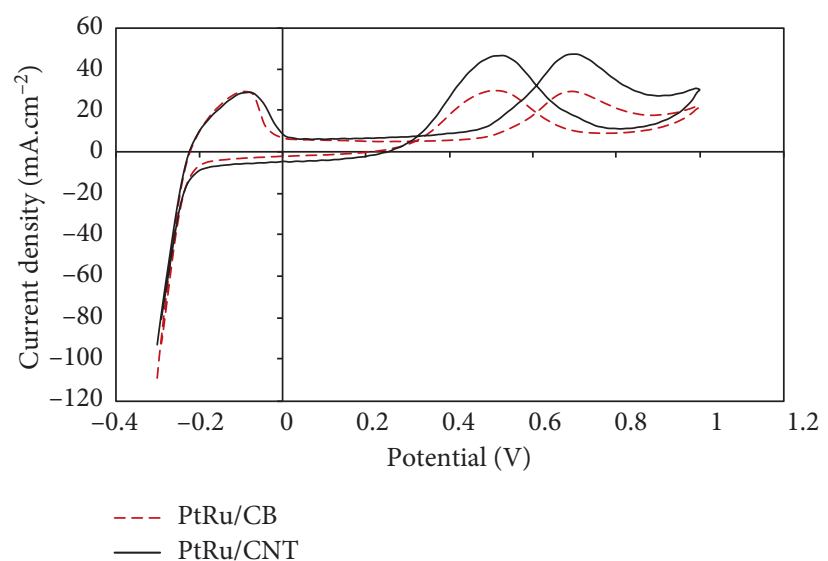

Figure 6: Cyclic voltammetry test of synthesized samples.

TABle 2: Comparison of the electrocatalytic activity, current density, and catalytic resistance.

\begin{tabular}{lccccc}
\hline Samples & $I_{f}\left(\mathrm{~mA} \mathrm{~cm}^{-2}\right)$ & $V_{f}(\mathrm{~V})$ & $I_{r}\left(\mathrm{~mA} \mathrm{~cm}^{-2}\right)$ & $V_{r}(\mathrm{~V})$ & $I_{f} / I_{r}$ \\
\hline $\mathrm{PtRu} / \mathrm{CB}$ & 29.22 & 0.695 & 29.58 & 0.51 & 0.98 \\
$\mathrm{PtRu} / \mathrm{CNT}$ & 47.2 & 0.7 & 46.51 & 0.525 & 1.014 \\
\hline
\end{tabular}

chronoamperometry analysis (Figure 7). In this test, a constant potential of $0.7 \mathrm{~V}$ is applied to the electrodes for $1000 \mathrm{~s}$, in an $\mathrm{N}_{2}$ saturated solution containing $0.5 \mathrm{M} \mathrm{H}_{2} \mathrm{SO}_{4}$ and $1 \mathrm{M}$ methanol. The current density is plotted as a function of the time.

The current density drops rapidly at first which is due to the production and accumulation of the intermediate species. Because of the higher resistance of $\mathrm{PtRu} / \mathrm{CNT}$ to poisoning species, it has less initial current drop compared to $\mathrm{PtRu} / \mathrm{CB}$, and after $1000 \mathrm{~s}$, the current density reaches $21.1 \mathrm{~mA} / \mathrm{cm}^{2}$. On contrary, PtRu/CB sample shows less resistance to the intermediate species, the highest current drop is observed at first seconds and finally reaches $8.3 \mathrm{~mA} /$ $\mathrm{cm}^{2}$, abound one-third of the CNT-supported PtRu [18].

Finally, after that, the fabricated passive methanol microfuel cell was built (Figure 8), and it was tested using two different sets of MEAs including CNT-based MEA (Pt/ CNT (cathode) and PtRu/CNT (anode)) and CB-based MEA (Pt/CB (cathode) and PtRu/CB (anode)). The analysis was conducted in a $3 \mathrm{M}$ methanol solution, and the polarization curves are shown in Figures 9 and 10.

By comparing the current-voltage curves of the two MEAs, at lower current densities $\left(0-10 \mathrm{~mA} / \mathrm{cm}^{2}\right)$-which is the region related to losses of activation energy and methanol crossover-a sharp decrease in the voltage is observed. At medium current densities (up to $70 \mathrm{~mA} / \mathrm{cm}^{2}$ ), the activity improvement of the catalyst leads to a more stable voltage. At high current densities (more than $70 \mathrm{~mA}$ / 


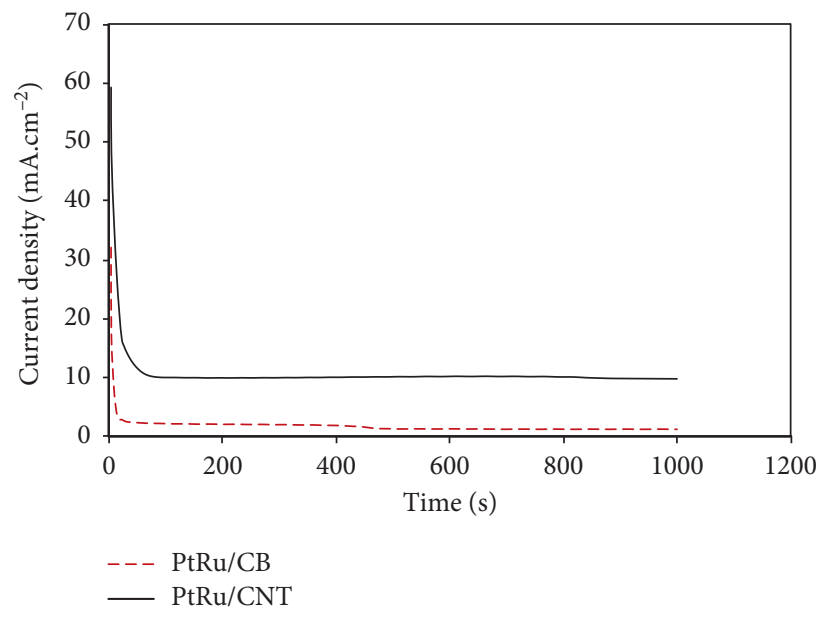

FIgURE 7: Chronoamperometry test of synthesized samples.
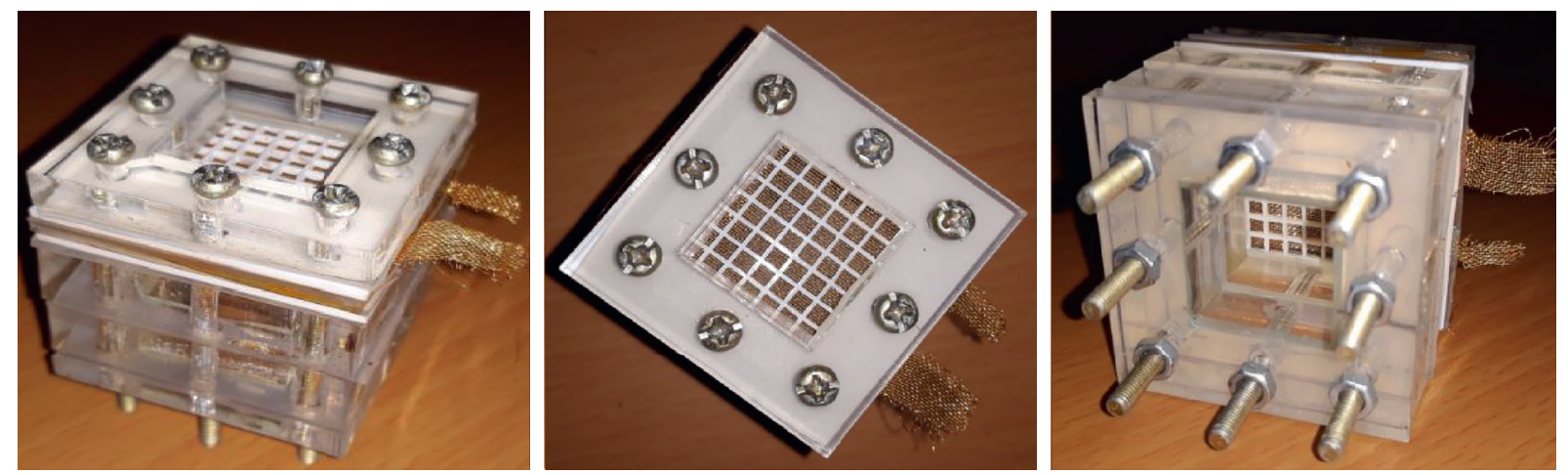

Figure 8: Schematic view of the fabricated methanol microfuel cell.

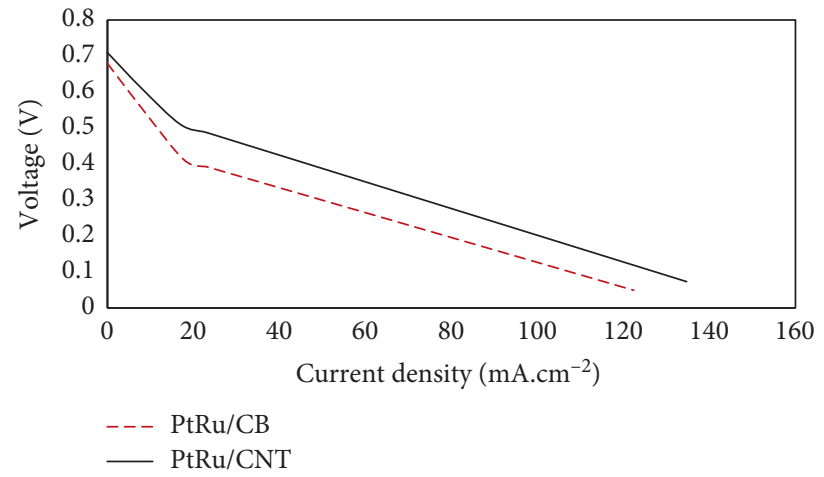

FIgURE 9: Polarization curves of the two sets of MEAs under the cell operation.

$\mathrm{cm}^{2}$ ), due to an increase in the chemical reaction rate, fuel consumption is increased. Hence, less porosity of $\mathrm{CB}$ structure compared to the MWCNT results in weaker fueling and sharper voltage drop. Therefore, it can be concluded that using PtRu/CNT can lead to a decrease in losses due to facilitating the mass transfer [19].
Because of the efficient dispersion and distribution of the catalyst particles on CNT, a significant increase in the power production capacity of the fuel cell is observed. Table 3 summarizes the results of the fuel cell tests. Based on the outcomes, by using CNT-supported electrocatalysts, the performance of the fuel cell has been increased about $37.1 \%$ 


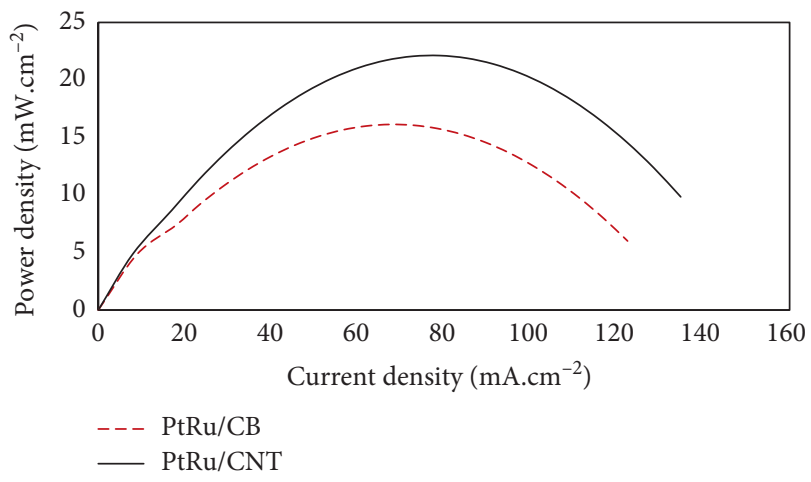

Figure 10: Power curves of the two sets of MEAs under the cell operation.

TABLE 3: Comparison of results of fuel cell maximum output power for different catalysts.

\begin{tabular}{lcccc}
\hline Test temperature $\left({ }^{\circ} \mathrm{C}\right)$ & Cathode catalysts & Anode catalysts & Maximum power density $\left(\mathrm{mW} \mathrm{cm}^{-2}\right)$ & Supported catalyst \\
\hline 60 & $\mathrm{Pt}$ & $\mathrm{PtRu}$ & $16 / 133$ & $\mathrm{CB}$ \\
60 & $\mathrm{Pt}$ & $\mathrm{PtRu}$ & $22 / 12$ & MWCNT \\
\hline
\end{tabular}

at maximum power density. The utilization of CNT instead of $\mathrm{CB}$ has increased fuel cell power and improves catalytic activity.

\section{Conclusions}

In this study, MWCNTs were employed to support PtRu particles as the electrocatalyst for DMFC, and the performance was compared with that of commercially used carbon black. Based on the tests and analysis conducted in this study, the following results have been obtained.

The EDX, SEM, and TEM analyses have confirmed the deposition of PtRu nanoclusters on the surface of carbon material and determined the weight percentage of elements. The XRD patterns have indicated the smaller metal particles and the higher surface area of electrocatalyst on the CNT compared to $\mathrm{CB}$, which stems from stronger interaction between CNT and metal catalyst.

Based on the cyclic voltammetry test in acid solution, the active electrochemical surface area for PtRu/CNT was calculated as $52.3 \mathrm{~m}^{2} / \mathrm{g}$ which is 1.9 times higher than that of $\mathrm{PtRu} / \mathrm{CB}\left(27.6 \mathrm{~m}^{2} / \mathrm{g}\right)$. The $\mathrm{CV}$ test also showed superior activity of $\mathrm{PtRu} / \mathrm{CNT}$ in methanol oxidation reaction (with $47.2 \mathrm{~mA} / \mathrm{cm}^{2}$ and $61.5 \%$ increase compared to PtRu/CB) and higher $I_{f} / I_{r}$ ratio, which means more tolerance to poisonous species. The chronoamperometry test showed that CNTsupported electrocatalysts are more durable and have a higher current density in the long term. Cell test revealed that maximum power density for $\mathrm{PtRu} / \mathrm{CNT}$ and $\mathrm{PtRu} / \mathrm{CB}$ was $22.12 \mathrm{~mW} / \mathrm{cm}^{2}$ and $16.133 \mathrm{~mW} / \mathrm{cm}^{2}$, respectively. Methanol oxidation onset potential which is a criterion for kinetic improvement of the MOR CNT has dropped from $5.3 \mathrm{~V}$ for $\mathrm{PtRu} / \mathrm{CB}$ to $4.4 \mathrm{~V}$ for $\mathrm{PtRu} / \mathrm{CNT}$. In conclusion, based on the extracted outcomes from this research, deploying CNTs in supporting PtRu nanoparticles remarkably improves the activity of electrocatalysts and consequently increases the output power of the fuel cell.

\author{
Abbreviations \\ CB: $\quad$ Carbon black \\ CNT: Carbon nanotube \\ CV: $\quad$ Cyclic voltammetry \\ DMFC: Direct methanol fuel cell \\ ECSA: Electrochemically active surface area \\ EDX: $\quad$ Energy-dispersive X-ray spectroscopy \\ GCE: Glassy carbon electrode \\ MEA: Membrane electrode assembly \\ MOR: Methanol oxidation reaction \\ MWCNT: Multiwalled carbon nanotubes \\ SEM: $\quad$ Scanning electron microscopy \\ TEM: Transmission electron microscopy \\ XRD: X-ray diffraction.
}

\section{Data Availability}

The experimental data used to support the findings of this study are included within the article.

\section{Conflicts of Interest}

The authors declare that they have no conflicts of interest.

\section{References}

[1] M. Ghalandari, H. Forootan Fard, A. Komeili Birjandi, and I. Mahariq, "Energy-related carbon dioxide emission forecasting of four European countries by employing data-driven methods," Journal of Thermal Analysis and Calorimetry, 2020, inpress.

[2] M. Khodaverdi, F. Pourfayaz, and M. Mehrpooya, "Nitrogendoped graphene prepared by low-temperature thermal treatment as an electrocatalyst support for methanol oxidation," Fuel Cells, inpress, 2021.

[3] M. Farooque and H. C. Maru, "Fuel cells-the clean and efficient power generators," Proceedings of IEEE, vol. 89, no. 12, pp. 1819-1829, 2001. 
[4] J. Lidderdale and T. J. P. Day, "Fuel cell CHP for buildings," in Proceedings of CIBSE Annual Conference, London, UK, November 2006.

[5] L. Wei, X. Yuan, and F. Jiang, "A three-dimensional nonisothermal model for a membraneless direct methanol redox fuel cell," Journal of Power Sources, vol. 385, pp. 130-140, 2018.

[6] S. Samad, K. S. Loh, W. Y. Wong et al., "Carbon and noncarbon support materials for platinum-based catalysts in fuel cells," International Journal of Hydrogen Energy, vol. 43, no. 16, pp. 7823-7854, 2018.

[7] H. Forootan Fard, M. Khodaverdi, F. Pourfayaz, and M. H. Ahmadi, "Application of N-doped carbon nanotubesupported $\mathrm{Pt}-\mathrm{Ru}$ as electrocatalyst layer in passive direct methanol fuel cell," International Journal of Hydrogen Energy, vol. 45, no. 46, pp. 25307-25316, 2020.

[8] L. Lu, H. Xu, R. Ren, and H. Zhao, "Graphite nanofibers as catalyst support for proton exchange membrane fuel cells at $80^{\circ} \mathrm{C}$," in Proceedings of 2010 Asia-Pacific Power Energy Engineering Conference, pp. 1-4, IEEE, Chengudu, China, March 2010.

[9] H. D. Jang, S. K. Kim, H. Chang et al., “Three-dimensional crumpled graphene-based platinum-gold alloy nanoparticle composites as superior electrocatalysts for direct methanol fuel cells," Carbon, vol. 93, pp. 869-877, 2015.

[10] C. Yang, X. Hu, D. Wang et al., "Ultrasonically treated multiwalled carbon nanotubes (MWCNTs) as PtRu catalyst supports for methanol electrooxidation," Journal of Power Sources, vol. 160, no. 1, pp. 187-193, 2006.

[11] N. Dongmulati and S. Baikeri, "Comparison of different types of polypyrimidine/CNTs/Pt hybrids in fuel cell catalysis," Journal of Nanoparticle Research, vol. 20, no. 8, 2018.

[12] X. Yu, Q. Zhang, Y. Ling, Z. Yang, and H. Cheng, "Promoted stability and electrocatalytic activity of PtRu electrocatalyst derived from coating by cerium oxide with high oxygen storage capacity," Applied Surface Science, vol. 455, pp. 815$820,2018$.

[13] A. M. Bilondi, M. Abdollahzadeh, M. J. Kermani, H. Heidary, and P. Havaej, "Numerical study of anode side CO contamination effects on PEM fuel cell performance; and mitigation methods," Energy Convers Manag, vol. 177, pp. 519-534, 2018.

[14] R. Praats, M. Käärik, A. Kikas et al., "Electrocatalytic oxygen reduction reaction on iron phthalocyanine-modified carbidederived carbon/carbon nanotube composite electrocatalysts," Electrochimica Acta, vol. 334, Article ID 135575, 2020.

[15] M. Kesava and K. Dinakaran, "SnO2 nanoparticles dispersed carboxylated Poly(arylene ether sulfones) nanocomposites for proton exchange membrane fuel cell (PEMFC) applications," International Journal of Hydrogen Energy, vol. 46, no. 1, pp. 1121-1132, 2021.

[16] A. K. Choudhary and H. Pramanik, "Addition of rhenium (Re) to Pt-Ru/f-MWCNT anode electrocatalysts for enhancement of ethanol electrooxidation in half cell and single direct ethanol fuel cell," International Journal of Hydrogen Energy, vol. 45, no. 24, pp. 13300-13321, 2020.

[17] H. Kuang, Y. Cheng, C. Q. Cui, and S. P. Jiang, "Carbon nanotubes-supported $\mathrm{Pt}$ electrocatalysts for $\mathrm{O} 2$ reduction reaction-effect of number of nanotube walls," Journal of Nanoscience and Nanotechnology, vol. 20, no. 5, pp. 27362745, 2020.

[18] K. Miecznikowski, "WO3 decorated carbon nanotube supported PtSn nanoparticles with enhanced activity towards electrochemical oxidation of ethylene glycol in direct alcohol fuel cells," Arabian Journal of Chemistry, vol. 13, no. 1, pp. 1020-1031, 2020.

[19] X. Ren, Q. Lv, L. Liu, A. Liu, B. Liu, and Y. Wang, "Facile synthesis of alloyed PtNi/CNTs electrocatalyst with enhanced catalytic activity and stability for methanol oxidation," Inorganic Chemistry Communications, vol. 120, Article ID 108130, 2020 